\title{
Insulin Clearance by the Isolated Perfused Livers of Insulin Deficient Rats
}

\author{
A.M. MeCarroll and K.D. Buchanan \\ Department of Medicine, The Queen's University of Belfast, Ireland \\ Received: April 4, 1973, and in revised form: July 3, 1973
}

\begin{abstract}
Summary. The ability of the liver to metabolise insulin in response to varying blood insulin levels was studied using normally fed, starved and streptozotocin diabetic rats. Insulin clearance by the livers of fasted and diabetic rats was significantly increased compared with normal fed controls. Administration of insulin to diabetic animals prior to liver perfusion, or an increase
\end{abstract}

in the concentration of the hormone in the perfusion medium used for normal livers resulted in a significant decrease in clearance. The percentage uptake of insulin during single passage through the livers of starved and diabetic animals was significantly greater than normal.

Key words: Diabetes, insulin, starvation, liver.
The liver has been shown by many workers to be a major organ of insulin degradation in the body, [9, $19,11,16]$. However, the physiological importance of this in total body insulin metabolism remains to be clarified. It has been previously demonstrated that the liver can alter its rate of degradation of corticosteroids in response to varying blood levels, $[17,22]$, and an autoregulatory negative feed-back mechanism has been postulated. The present investigation was undertaken to study the response of the liver to fluctuations in blood insulin levels.

\section{Materials and Methods}

Male albino rats of Wistar strain weighing 150 $200 \mathrm{~g}$ were used throughout and the isolated intact rat liver perfusion technique of Miller et al. [8] and. Schimassek [14], as modified by Hems et al. [4], was employed. Each insulin clearance experiment was preceded by a control perfusion period of $15 \mathrm{~min}$. Pork insulin (Novo, 10 times recrystallised, Lot. No. S23267) of potency 25 I.U. per milligramme was then added to the perfusate to give a final concentration of 200 microunits $/ \mathrm{ml}$. unless otherwise stated in the protocol. A further $6 \mathrm{~min}$ perfusion was allowed for equilibration [15], after which the first of a series of approximately $0.5 \mathrm{ml}$ samples was taken directly from the hepatic effluent. Further samples were taken at 3, 6, 9, 14, 19, 24 , and $34 \mathrm{~min}$. Samples were immediately centrifuged to remove red blood cells and stored frozen at $-20^{\circ} \mathrm{C}$. Insulin in the samples and in the plasma of experimental animals was measured by the radioimmunoassay technique of Yalow and Berson, [21] as modified by Herbert et al. [5] and Buchanan and McCarroll [2].

\section{Calculation of Results}

The results were calculated as the percentage of maximal (initial) concentration determined 6 min after the insulin had been added to the perfusate and the half life was determined from the linear regression equation of insulin concentration against time. No correction was made for the error introduced by the decreasing perfusate volume, as this was less than $5 \%$.

\section{Experimental Protocol 1}

a) One group of animals was made insulin deficient by starvation for $72 \mathrm{~h}$, but allowed free access to water. At the end of the starvation period isolated liver perfusion was carried out. The livers of fully fed litter mates acting as controls were also perfused.

b) A second group of animals was made insulin deficient by intravenous injection of streptozotocin $(65 \mathrm{mg} / \mathrm{kg}$ body weight) dissolved immediately beforehand in a citrate-phosphate buffer $\mathrm{pH}$ 4.5. At the same time rats of similar weight were put aside to act as controls. Both groups of animals were maintained on normal diets for periods varying from 2 to 6 weeks and then their livers were perfused in the fed state. Plasma glucose at the time of perfusion was measured by a glucose-oxidase method on an Auto Analyzer.

Insulin deficiency in both starved and diabetic animals was confirmed by plasma insulin estimations made at the time of perfusion.

\section{Experimental Protocol 2}

A second group of streptozotocin-treated animals was given Protamine Zinc Insulin 10 I.U. subcutaneously twice daily for $48 \mathrm{~h}$, after which time liver perfusion was carried out.

\section{Experimental Protocol 3}

Liver perfusion studies were carried out with 1000 microunits of insulin per $\mathrm{ml}$ of perfusate in 8 normally fed rats.

\section{Experimental Protocol 4}

The "capture" mechanism of the liver. Perfusion medium without added insulin was allowed to circulate 
through the livers of 3 groups of rats for $15 \mathrm{~min}$ as follows:

a) 5 fed rats;

b) 5 rats which had been starved for $72 \mathrm{~h}$;

c) 5 rats which had been made diabetic by injection of streptozotocin $(65 \mathrm{mg} / \mathrm{kg}$ body weight.) After this equilibration period identical perfusate to which 200 microunits of insulin per $\mathrm{ml}$ had been added was allowed a single passage through the livers; samples of insulin-containing perfusate were taken before and afterwards.
The effect on hepatic insulin half life of insulin administration to diabetic rats is seen in Table 2. There is a highly significant increase in insulin $t 1 / 2$ in treated animals as compared with controls.

Table 3 shows the effect on hepatic insulin half life of increasing the concentration of insulin in the perfusion medium of normally fed rat livers. Again the insulin half life is significantly increased with increase in substrate concentration.

Table 4 shows the percentage uptake of insulin by fed, starved and streptozotocin treated livers during

Table 1. Hepatic insulin half-life in controls and insulin deficient rats. ( $M \pm S E M)$

\begin{tabular}{lccl}
\hline Group & $\begin{array}{l}\text { No. of } \\
\text { rats }\end{array}$ & $\begin{array}{l}\text { Hepatic insulin } \\
\mathrm{t} 1 / 2 \mathrm{~min} .\end{array}$ & $\begin{array}{l}\text { Significance of difference } \\
\text { in half-life between } \\
\text { control and test groups }\end{array}$ \\
\hline $\begin{array}{l}\text { 1. Starved } 72 \mathrm{~h} \\
\text { 2. Fed Control }\end{array}$ & $\mathbf{7}$ & $8.35 \pm 0.80$ & $t=7.6771$ \\
3. Streptozotocin & 10 & $18.1 \pm 0.81$ & $p<0.0005$ \\
$\begin{array}{l}\text { Treated } \\
\text { 4. Control }\end{array}$ & 19 & $8.9 \pm 0.46$ & $t=5.7453$ \\
\hline
\end{tabular}

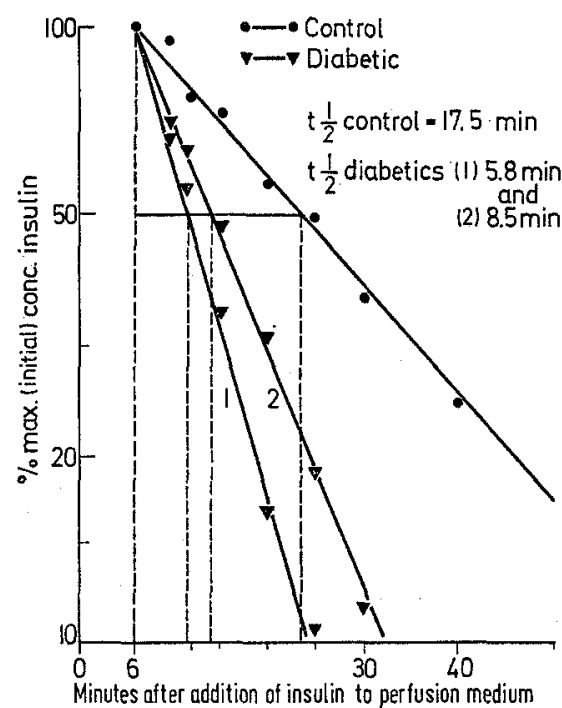

Fig. 1. Insulin decay curves for diabetic animals and control

\section{Results}

Streptozotocin administered to rats in a dose of $65 \mathrm{mg} / \mathrm{kg}$ body weight invariably produced a severe diabetic state with wasting, polyuria and gross hyperglycaemia.

Table 1 shows the hepatic insulin $t / 1 / 2$ in starved animals, streptozotocin treated rats and normally fed controls. It will be seen that $t \frac{1}{2}$ is significantly shorter in the insulin deficient animals than in controls.

Fig. 1 shows two individual decay curves for streptozotocin-treated animals as compared with a control. single passage of perfusate. There was a significantly greater uptake by the livers of both insulin deficient groups as compared with normal.

\section{Discussion}

Insulin clearance by the livers of insulin deficient rats, whether induced by starvation or the administration of streptozotocin, was found to be significantly greater than that by controls (Table 1). These findings agree with those of others using either liver slices [10], the intact perfused liver of the alloxanised bullfrog [20], or the isolated perfused liver of the rat [7]. It has also been found that insulin clearance by the normal liver decreased significantly as the concentration of hormone in the perfusion medium was increased [7]. This observation has been confirmed in the present study. (Table 3). We have shown a similar effect following the administration of insulin to diabetic animals in vivo (Table 2). However, earlier work showed a decrease of "insulinase" activity in liver extracts and homogenates of liver tissue from fasted rats [1] and very recently a group using similar techniques also found a decrease in insulin degradation in insulin deficient tissue which. reverted to control levels when the concentration of hormone increased [18]. Based on these observations it is argued that a physiologically important, autoregulatory system for insulin degradation exists in the liver [18].

The conflict in the published data can possibly be explained by the difference in the preparations used by the different workers. This is all the more likely in view of the fact that Mirsky [9 and 10] obtained two sets of diametrically opposed results by merely chang. 
ing the experimental preparation. When tissue extracts or homogenates are used only enzymatic activity is studied, whereas with tissue slices or with isolated organ perfusion systems, as in the present investigation, the intact cell is studied. At least two other steps are, therefore, necessarily interposed between the union of substrate and enzyme, namely uptake or "capture" of substrate by the cells, and transcellular penetration by the hormone to reach the reaction site. The liver has been shown to remove 20 to $50 \%$ of insulin during the for example, to the concept of renal tubular maximum (Tm), or else they are actually functionally inhibited. The limitations of our method do not allow us to draw any conclusions regarding the final enzymatic step in the breakdown of insulin.

An increased rate of insulin clearance in starvation seems reasonable if one accepts the hypothesis that the insulin-fuel inter-relationship in starvation determines blood glucose levels, and is mediated via the pancreatic-hepatic axis, [3]. Accordingly, with a diminished

Table 2. Hepatic insulin half-life in controls and insulin-treated diabetic rats ( $M \pm$ $S E M$ )

\begin{tabular}{llll}
\hline Group & $\begin{array}{l}\text { No. of } \\
\text { rats }\end{array}$ & $\begin{array}{l}\text { Hepatic insulin } \\
\text { min. }\end{array}$ & $\begin{array}{l}\text { Significance of difference } \\
\text { in half-life between } \\
\text { contro land treated group }\end{array}$ \\
\hline $\begin{array}{l}\text { 1. Diabetic treated with } \\
\begin{array}{l}\text { P.Z.I. } \\
\text { 2. Control }\end{array}\end{array}$ & 7 & $35.35 \pm 3.5$ & $t=5.5759$ \\
\hline
\end{tabular}

Table 3. Hepatic insulin half-life in the normal liver in the presence of increased insulin concentration $(M \pm S E M)$

\begin{tabular}{lcll}
\hline $\begin{array}{l}\text { Amount of insulin } \\
\text { in perfusion medium }\end{array}$ & $\begin{array}{l}\text { No. of } \\
\text { rats }\end{array}$ & $\begin{array}{l}\text { Hepatic insulin } \\
\text { half-life } \\
\text { min. }\end{array}$ & $\begin{array}{l}\text { Significance of difference } \\
\text { in half-life between } \\
\text { control and test group }\end{array}$ \\
\hline $1.200 \mathrm{uU} / \mathrm{ml}$. & 10 & $\mathbf{1 8 . 1 0 \pm 1 . 2}$ & $\begin{array}{l}t=11.3415 \\
p<0.0005\end{array}$ \\
\hline $2.1000 \mathrm{uU} / \mathrm{ml}$. & 8 & $37.59 \pm 2.86$ & $p<$ \\
\hline
\end{tabular}

Table 4. Percentage uptake of insulin by fed, starved and diabetic livers on single passage $(M \pm S E M)$

\begin{tabular}{llll}
\hline Group & No. of & $\begin{array}{l}\text { Percentage uptake } \\
\text { of insulin }\end{array}$ & $\begin{array}{l}\text { Significance of difference } \\
\text { in uptake between } \\
\text { control and test groups }\end{array}$ \\
\hline 1. Control & 5 & $22.2 \pm 3.3$ & $t=2.0670$ \\
2. Starved & 5 & $42.4 \pm 9.1$ & $p<0.05$ \\
3. Diabetic & 5 & $38.87 \pm 2.2$ & $t=4.5055$ \\
& & $p<0.0025$ \\
\hline
\end{tabular}

first single passage through it, indicating its vast capacity for hormone uptake $[6,13]$. It was concluded from studies on the "capture" mechanism of the liver that the ultimate rate limiting step in the hepatic breakdown of insulin might be its transfer from the site of "capture" to the degrading enzyme system [11]. It seems clear that intact cell preparations are unsuited to the study of enzymatic degradation, because of the interposition of these two interfering factors.

Our clearance finding's favour the suggestion that "capture" or uptake of insulin by binding sites and transcellular transport of hormone, both of which are dependent on the presence of the intact cell, are more active in the insulin deficient liver. The significantly greater percentage uptake of insulin by starved and diabetic livers during a single transhepatic passage lends further support to the suggestion. Conversely, at high concentrations of substrate, either the capacity of these mechanisms is exceeded in a manner similar, fuel supply there is decreased requirement for circulating insulin and a need for greater insulin clearance by the liver. In diabetes mellitus, however, where maximum conservation of circulating hormone might be expected, this mechanism appears inappropriate. It may possibly contribute to often massive insulin requirements observed clinically in cases of diabetic ketosis.

Acknowledgements. We wish to thank Novo Laboratories, Copenhagen, for the supply of insulin used in this study. A.M. McCarroll wishes to thank the Research Committee of the Royal Victoria Hospital, Belfast, for the Fellowship during which this work was carried out.

\section{References}

1. Broh-Kahn, R.H., Mirsky, I.A.: The inactivation of insulin by tissue extracts. II. The effect of fasting 
on the insulinase content of rat liver. Arch. Biochem. 20, 10-14 (1949)

2. Buchanan, K.D., MeCarroll, A.M,: Rádioimmunoassay Methods. p. 136-142 Ist ed. (Kirlkham, K.E., Hunter, W.M.) Edinburgh: E. and S. Livingstone 1971

3. Cahill, G.F., Jr., Herrera, M.G., Morgan, A.P., Soeldner, G.A. Jr., Kipnis, D. M.: Hormone - fuel inter-relationships during fasting. J. clin. Invest. 45, $1751-1769$ (1966)

4. Hems, R., Ross, B.D., Berry, M.N., Krebs, H.A.: Gluconeogenesis in the perfused rat liver. Biochem. J. 101, 284-292 (1966)

5. Herbert, V., Lau, K., Gottlieb, C.W., Bleicher, S.J.: Coated charcoal immunoassay of insulin J. clin. Endochrin. 25, 1375-1384 (1965)

6. Kaplan, N., Madison, L.L.: Effects of endogenous insulin secretion on the magnitude of hepatic binding of labeled insulin during a single trans-hepatic circulation in human subjects. Clin. Res. 7, 248 (1959)

7. Marshall, A., Gingerich, R.L., Wright, P.H.: Hepatic metabolism of insulin in vitro. Clin. Res. 18, $33(1970)$

8. Miller, L.L., Bly, C.G., Watson, M.L., Bale, W.F.: The dominant role of the liver in plasma protein synthesis. J. exp. Med. 94, 431-453 (1951)

9. Mirsky, I.A., Broh-Kahn, R.H.: The inactivation of insulin by tissue extracts. I The distribution and properties of insulin inactivation extracts (insulinase). Arch. Biochem. 20, 1-9 (1949)

10. Mirsky, I.A., Perisutti, G.: The inactivation of insulin by liver slices of the rat. Endocrinology 52, $698-704(1953)$

11. Mortimore, G.E., Tietze, F.: Studies on the mechanisn of capture and degradation of insulin I 131 by the cyclically perfused rat liver. Ann. N.Y. Acad. Sci. 82, $329-337$ (1959)

12. Mortimore, G.E., Tietze, F., Stetten, D. Jr.: Metabolism of insulin $\mathrm{I}^{131}$. Studies in isolated, perfused rat liver and hind limb preparations. Diabetes 8 , $307-314$ (1959)

13. Samols, E., Ryder, J.A.: Studies of tissue uptake of insulin in man using a differential immunoassay for endogenous and exogenous insulin. J. clin. Invest. 40, 2092-2102 (1961)

14. Schimassek, H.: Metabolite des Kohlenhydratstoffwechsels der isoliert perfundierten Rattenleber. Biochem. Z. 336, 460-467 (1963)

15. Solomon, S.S., Fenster, L. F., Ensinck, J.W., Williams R.H.: Clearance studies of insulin and non-suppressible insulin-like activity (NSILA) in the rat liver. Proc. Soc. exp. Biol. (N.Y.) 126, 166-169 (1967)

16. Tomizawa, H.H., Varandani, P.T.: Glutathione insulin transhydrogenase of human liver. J. biol. Chem. 240, $3191-3194$ (1965)

17. Uete, T., Blair, J.A. Jr.: Autoregulatory system of Corticosteroid metabolism in the liver. Metabolism 14, 904-911 (1965)

18. Uete, T., Tsuchikura, H.: Autoregulatory system of insulin degradation in liver. I. Decreased 131I-insulin degradation in the liver of insulin deficient rats. J. Biochem. (Tokyo) 72, 157-163 (1972)

19. Vaughan, M.: The inactivation of insulin by an enzyme from rat liver. Biochem. biophys. Acta. (Amst.) 15, 432-433 (1954)

20. Weisenfeld, S., Jauregui, R.H., Goldner, M.G.: Inactivation of insulin by the isolsted liver of the bullfrog. Amer. J. Physiol. 188, 45-48 (1957)

21. Yalow, R.S., Berson, S.A, : Immunoassay of endogenous plasma insulin in man. J. clin. Invest. 39, $1157-1175(1960)$

22. Yates, F.E.: Contributions of the liver to steadystate performance and transient responses of the adrenal cortical system. Fed. Proc. 24, 723-730 (1965)

Dr. A.M. McCarroll

Department of Medicine

Queen's University of Belfast

Clinical Institute

Grosenor Road

Belfast 12

Ireland 